\title{
"Sendiko Dawuh Ngarso Dalem" \\ (Studi Kasus Makna Kerja pada Abdi Dalem Punakawan di Keraton Ngayogyakarta Hadiningrat)
}

\author{
Pradita Nindya Aryandha ${ }^{1}$, Zainal Mustafa Elqadri ${ }^{2}$ \\ Universitas Islam Indonesia \\ Email: nindyaaryandha93@gmail.com
}

\begin{abstract}
This research is titled Sendiko Dawuh Ngarso Dalem (Case Study of Punokawan Courtiers in Keraton Ngayogyakarta Hadiningrat). The purpose of this research is to understand the framework of the maning Punokawan Courtiers"s work in Keraton Ngayogyakarta Hadiningrat after obtaining a salary sourced the Yogyakarta Privileges Fund. This research is considered as qualitative research with case study approach. This research uses interview as data collecting method. The informants in this study are Dr. Threresia Suharti, S.S.T., M.S and Drs. Antonius Sutarno, who work as Punakawan Tepas and Caos Courtiers who has served for more than 30 years. In order to know data validation, it is therefore using credibility test and transferability test. Data test method uses triangulation, whereas data analysis method uses reduction data, display data, and conclusion drawing/verification. This research found that the maning of work for the courtiers was interpreted as a calling.
\end{abstract}

Keywords: Courtier, Keraton Ngayogyakarta Hadiningrat, Meaning of Work

\section{PENDAHULUAN}

Indonesia merupakan sebuah negara kepulauan terbesar di dunia yang terletak di Asia Tenggara. Melintang di katulistiwa antara Benua Asia dan Australia serta Samudera Pasifik dan Samudera Hindia. Indonesia lahir dari kerajaan-kerajaan besar seperti Kerajaan Majapahit, Kerajaan Mataram, dan Kerajaan Kutai. Namun jika dilihat secara keseluruhan, terdapat banyak kerajaan yang pernah berjaya di bumi pertiwi. Bahkan beberapa kerajaan masih ada yang eksis sampai sekarang. Hasil penelitian Suhardi bekerjasama dengan Kementerian Dalam Negeri pada tahun 2012 (dalam Kurniawan, 2012) menyatakan bahwa di balik pemerintahan demokrasi Indonesia saat ini ternyata masih terdapat 186 kerajaan yang masih eksis di tanah air. Dengan jumlah sebanyak itu, disarankan agar pemerintah membentuk undang-undang yang mengatur tentang keberadaan kerajaan tersebut. Caranya bukan dengan membangun konstitusi pemerintahan tetapi diperlukan pendanaan dari anggaran pendapatan dan belanja negara (APBN) untuk pendekatan seni, budaya, dan pariwisata.

Keraton Ngayogyakarta Hadiningrat merupakan salah satu kerajaan yang masih eksis sampai saat ini. Menurut Soenarto (2012), keraton ini terletak di tengah Kota Yogyakarta. Keberadaannya tertulis dalam buku sejarah keraton

Bisman (Bisnis dan Manajemen): The Journal Of Business and Management 
tertanggal 7 Juni 1756. Kerajaan Mataram dibagi menjadi dua yang disebut dengan sesigar semangka yang sebagian wilayahnya masuk dalam Negeri Ngayogyakarta Hadiningrat dan sebagian masih tetap di Surakarta Hadiningrat. Pembagian ini melalui perjanjian daerah Giyanti tanggal 13 Februari 1755 yang disahkan oleh Hindia Belanda VOC dan dikenal dengan Perjanjian Giyanti.

Menurut Badan Pengawas Keuangan dan Pembangunan/BPKP (2015) keberadaan Keraton Ngayogyakarta Hadiningrat memperoleh kedudukan tersendiri di Republik Indonesia yang dikuatkan dengan pemberian keistimewaan untuk Yogyakarta. Substansi istimewa bagi Daerah Istimewa Yogyakarta (DIY) terdiri dalam tiga hal, yakni istimewa dalam hal sejarah pembentukan pemerintah daerah istimewa, istimewa dalam hal bentuk pemerintahan Daerah Istimewa Yogyakarta yang terdiri dari penggabungan dua wilayah Kesultanan dan Pakualaman menjadi satu daerah setingkat provinsi yang bersifat kerajaan dalam satu kesatuan wilayah Negara Kesatuan Republik Indonesia, dan istimewa dalam hal kepala pemerintahan Daerah Istimewa Yogyakarta yang dijabat oleh sultan dan adipati yang bertahta tetap dalam kedudukan seorang sultan dan adipati yang bertahta sesuai dengan angka urutan tahtanya.

Setelah diproklamasikan keberadaan Keraton Ngayogyakarta Hadiningrat pada tanggal 13 Maret 1755, Keraton Ngayogyakarta Hadiningrat membutuhkan aparatur negara yang berasal dari golongan sipil maupun militer. Abdi dalem adalah aparatur sipil, sedangkan aparatur militernya merupakan prajurit keraton. Abdi dalem ini bertugas sebagai pelaksana operasional di setiap organisasi yang dibentuk oleh Sultan. Roda pemerintahan tidak akan berjalan, apabila tak ada abdi dalem yang membantu keberlangsungan aktivitas operasional di dalam keraton. (kratonjogja.id, 2016)

Selain menjalankan tugas operasional pada setiap organisasi di keraton, Abdi Dalem juga merupakan 'abdi budaya'. Abdi budaya berarti orang yang dapat dan mampu memberi suri tauladan bagi masyarakat luas. Abdi dalem harus dapat menjadi contoh kehidupan di masyarakat, bertindak berdasarka unggah-ungguh dan paham akan tata krama. Oleh karena itulah, Abdi Dalem Keraton Ngayogyakarta selalu menunjukkan senyum selalu merekah, ramah, dan sopan santun yang tinggi. (kratonjogja.id, 2016)

Abdi dalem dibagi menjadi dua macam, yakni Abdi Dalem Keprajan dan Abdi Dalem Punakawan. Abdi Dalem Keprajan memiliki derajat dan kasta lebih tinggi dibanding Punakawan. Jumlah Abdi Dalem Keprajan juga tidak begitu banyak dibanding dengan jumlah Abdi Dalem Punakawan yang mencapai ratusan. Secara tugas mereka sama-sama mengabdi pada pihak keraton. Yang membedakan kedua abdi dalem tersebut adalah pemberian uang pituas (gaji) dari pihak keraton. Untuk Abdi Dalem Keprajan tidak mendapatkan uang pituas, sebab sudah mendapatkan uang pensiun. Sedangkan Punakawan mendapatkan uang pituas meski jumlahnya kecil (Prabowo, 2011).

Kedua tingkatan abdi dalem tersebut juga memiliki struktur organisasi. Mulai dari ketua, sekretaris, bendahara, dan jumlah keanggotaan. Pekerjaan masing-masing abdi dalem berbeda sesuai porsinya. Abdi Dalem Keprajan berasal dari Tentara Nasional Indonesia (TNI), Kepolisian Negara Republik Indonesia (Polri), dan Pegawai Negeri Sipil (PNS) yang diterima dan diangkat sebagai abdi 
dalem. Pada umumnya, Abdi Dalem Keprajan merupakan orang-orang yang memasuki masa pensiun kemudian mendarmabaktikan waktu, ilmu, dan tenaganya untuk membantu keraton secara suka rela. Abdi Dalem Keprajan tidak selalu hadir di keraton. Biasanya mereka hanya hadir saat momen tertentu atau upacara adat yang dihelat keraton. Sedangkan Abdi Dalem Punakawan harus mengisi presensi kehadiran ketika piket jaga di lingkungan keraton. Itu pun tidak dilakukan setiap hari, ada yang sepuluh hari sekali, 12 hari sekali, dan ada juga yang 15 hari sekali (kratonjogja.id, 2016).

Abdi dalem yang berasal dari kalangan masyarakat umum disebut Abdi Dalem Punakawan. Abdi dalem ini merupakan tenaga operasional yang menjalankan tugas keseharian di dalam keraton. Abdi Dalem Punakawan ini dikelompokkan lagi kedalam dua golongan, yaitu Abdi Dalem Punakawan Tepas dan Abdi Dalem Punakawan Caos. Abdi Dalem Punakawan Tepas mempunyai jam kerja selayaknya pekerja kantoran, sedangkan Abdi Dalem Punakawan Caos hanya menghadap ke keraton setiap periode sepuluh hari sekali. Mereka melakukan ini untuk menunjukkan tanda hormat dan kesetiaan sebagai abdi dalem (kratonjogja.id, 2016).

Mulai Desember 2013, terdapat kesepakatan antara Kementerian Keuangan Republik Indonesia (RI) dengan Sri Sultan Hamengku Buwono X bahwa Sri Sultan, Sri Paduka Pakualam, serta abdi dalem akan medapatkan gaji yang berasal dari Dana Keistimewaan (Danais). Besaran gaji tersebut beragam tergantung pangkat. Gaji ini sebagai penjaga budaya dan besarannya ditetapkan menggunakan surat keputusan. Oleh karena itu gaji ini berbeda dengan gaji yang diterima PNS. Meskipun demikian, kekucah sih dalem masih diberikan kepada para abdi dalem, namun jumlahnya tidak besar berdasarkan pangkat abdi dalem dan kebijakan sultan. Kekucah ini diberikan setiap terdapat kegiatan Keraton Ngayogyakarta seperti Selasa Wagen, Ayahan Grebeg, dan lain-lain (Anugraheni, 2013).

Untuk gaji atau honor dari Danais ditetapkan dengan surat keputusan. Sementara untuk kekucah berdasarkan pangkat abdi dalem dan kebijakan Sultan. Untuk kekucah seorang Jajar (abdi dalem pangkat terendah) mendapat kekucah Rp 15 ribu per bulan dan paling tinggi adik Sultan sebesar Rp 90 ribu per bulan. Sedangkan gaji dari alokasi dana keistimewaan untuk Tepas lebih tinggi ketimbang Caos. Untuk Tepas paling rendah Rp 1,1 juta per bulan dan paling tinggi Rp 2,5 juta per bulan. Bahkan Sultan yang bertahta mendapat honor atau gaji Rp 3,8 juta per bulan. Untuk honor Caos terendah Rp 150 ribu per bulan dan tertinggi Rp 400 ribu per bulan. Total dana keistimewaan yang merupakan dana alokasi khusus (DAK) dari pusat untuk honor abdi dalem keraton sebesar Rp 900 juta per bulan untuk 1.800 orang abdi dalem. (Awo, 2018).

Dalam Soenarto (2012), Djoko (2008) menjelaskan bahwa pengabdian merupakan perwujudan kesetiaan kepada pemimpinnya (rajanya) dengan mengutamakan perbuatan dan pemikirannya dengan rasa hormat, rasa cinta, dan kasih sayang serta semua ikatan dilakukan dengan penuh keikhlasan. Selain itu Jatiningrat (2008) juga menjelaskan bahwa kesetiaan merupakan tanggung jawab kepada Sang Pencipta Alam dengan segala isinya. Konsep pengabdian dalam 
bekerja oleh abdi dalem keraton merupakan keunikan tersendiri yang dapat diteliti.

Pasca munculnya kesepakatan antara Kementerian Keuangan RI dengan Sri Sultan Hamengku Buwono X tentang Dana Keistimewaan Yogyakarta, muncul pertanyaan orang awam tentang peran abdi dalem di Keraton Ngayogyakarta Hadiningrat. Abdi dalem keraton kini merupakan seorang pengabdi raja atau seorang pegawai? Motto abdi dalem, yakni "pejah gesang nderek Sultan" yang berarti abdi dalem ini sudah berniat mengabdi untuk sang raja selama fisiknya kuat hingga wafat jangan sampai bergeser maknanya. Terdapat kekhawatiran, masyarakat sipil memilih menjadi abdi dalem karena menganggap kini abdi dalem tidak hanya sebuah pengabdian tetapi juga sebuah mata pencaharian. Hal ini dikarenakan mereka akan memperoleh gaji yang lebih mensejahterakan.

Pendalaman informasi mengenai abdi dalem terutama Abdi Dalem Punakawan di Keraton Ngayogyakarta Hadiningrat perlu dilakukan yang berkaitan dengan makna kerja. Hal ini dikarenakan sebelumnya Abdi Dalem Punakawan hanya memperoleh pituas (gaji) dari Keraton yang jumlahnya kecil tetapi kini mereka juga memperoleh gaji bersumbar Dana Keistimewaan Yogyakarta dengan nominal yang lebih besar dan dianggap lebih mensejahterakan. Tujuan penelitiannya adalah untuk mengetahui gambaran makna kerja pada Abdi Dalem Punakawan di Keraton Ngayogyakarta Hadiningrat setelah mempeoleh gaji bersumber dari Dana Keistimewaan Yogyakarta.

\section{Makna Kerja}

Makna kerja adalah sekumpulan nilai-nilai, keyakinan-keyakinan, sikap, dan harapan yang orang-orang miliki dalam hubungannya dengan kerja (Gaggioti dalam Siti, 2013). Frankl (dalam Koeswara, 1992) menambahkan bahwa makna kerja bukan diperoleh dari pekerjaan itu sendiri, yang dipentingkan adalah bagaimana individu dapat menunjukkan keberaniannya dalam berekspresi, menunjunkkan keunikannya dan keberaniannya dalam bekerja sehingga mendapatkan makna dan komitmen pribadi terhadap pekerjaannya serta menjadi tanggung jawab terhadap kehidupan pribadi dan kehidupan sesamanya.

Menurut Wrzesniewski et al., (2003) makna kerja yang dimaknai dapat mempengaruhi para pegawai dalam pekerjaannya. Makna kerja tersebut adalah sebagai berikut:

1. Bekerja sebagai sebuah pekerjaan. Pekerjaan dianggap sebagai pendapatan pokok dan sebagai sebuah sarana untuk mencapai tujuan (menafkahi keluarga). Ketika individu tidak memperoleh pendapatan maka ia akan berhenti.

2. Pekerjaan sebagai sebuah karir. Pekerjaan dipandang sebagai motivasi untuk berprestasi, stimulus kebutuhan untuk bersaing atau meningkatan prestis atau kepuasan.

3. Pekerjaan sebagai sebuah panggilan. Pekerjaan adalah sumber kebermaknaan diri. Invidivu yang memandang pekerjaan sebagai sebuah panggilan akan mengenali dan percaya bahwa pekerjaan yang dilakukannya mampu 
memberikan kontribusi kepada lingkungan sosial atau pekerjaan sebagai sarana untuk melayani diri sendiri dan orang lain.

Makna kerja menurut Singh (dalam Herudiarti, 2013) merupakan penghayatan individu dalam memenuhi kebutuhan ekonomi dengan kegiatan bekerja dalam sebuah lingkungan kerja. Lebih lanjut dijelaskan oleh Chalofsky (dalam Herudiati, 2013), makna kerja merupakan suatu kontribusi yang signifikan untuk menemukan tujuan hidup seseorang. Kondisi ini mendukung untuk melaksanakan pekerjaan dengan semangat kerja dan pandangan yang menjadi dasar spiritual seseorang dalam bekerja. Hal ini menekankan adanya kesesuaian tugas dengan motivasi diri dalam bekerja yang bertujuan untuk mendapatkan penghargaan atas hasil kerja.

\section{METODE PENELITIAN \\ Pendekatan Penelitian}

Penelitian adalah salah satu cara mencari fakta-fakta. Dalam penelitian ini menggunakan pendekatkan kualitatif. Pendekatan kualitatif digunakan untuk menggali informasi lebih dalam. Pendekatan kualitatif menurut Moleong (2008) adalah penelitian yang menggunakan pendekatan naturalistik untuk mencari dan menemukan pengertian atau pemahaman tentang fenomena dalam suatu latar dalam konteks khusus.

Penelitian ini menggunakan pendekatan studi kasus untuk mendeskripsian hasil penelitian dan berusaha menemukan gambaran menyeluruh mengenai suatu keadaan. Yin (2014) mengatakan bahwa studi kasus merupakan suatu inkuiri empiris yang menyelidiki fenomena di dalam konteks kehidupan nyata, apabila batas-batas antara fenomena dan konteks tak tampak dengan tegas serta memanfaatkan berbagai sumber. Pendekatan ini memungkinkan peneliti untuk mempertahankan karakteristik holistik dan bermakna dari peristiwa-peristiwa kehidupan nyata. Keunikan dari studi kasus adalah kemampuannya untuk menghubungkan berbagai jenis bukti baik dokumen, peralatan, wawancara, dan observasi.

\section{Pengumpulan Data}

Teknik pengumpulan data merupakan langkah yang harus dilakukan peneliti untuk memperoleh informasi yang diperlukan selama penelitian berlangsung. Teknik pengumpulan data yang digunakan dalam penelitian ini adalah wawancara. Wawancara menurut Esterberg (2002) merupakan pertemuan dua orang untuk bertukar informasi dan ide melalui Tanya jawab sehingga dapat dikonstruksikan makna dalam suatu topik tertentu. Wawancara digunakan sebagai teknik pengumpulan data apabila peneliti ingin melakukan studi pendahuluan untuk menemukan permasalahan yang harus diteliti tetapi juga apabila peneliti ingin mengetahui hal-hal dari narasumber lebih dalam. Teknik pengumpulan data ini mendasarkan diri pada laporan tentang diri sendiri atau setidaknya pada pengetahuan dan atau keyakinan pribadi.

\section{Teknik Analisis Data}

Sugiyono (2013) mengatakan teknik analasis data pada penelitian kualitatif, yaitu: 
1. Analisis data sebelum di lapangan

Penelitian kualitatif telah melakukan analisis data sebelum peneliti memasuki lapangan. Analisis dilakukan terhadap data hasil studi pendahuluan atau data sekunder yang akan digunakan untuk menentukan fokus penelitian. Namun dalam fokus penelitian, masiH bersifat sementara dan akan berkembang ketika peneliti berada di lapangan dan setelah dari lapangan.

2. Analisis data di lapangan.

Analisis data dilakukan pada saat pengumpulan data berlangsung dan setelah selesai pengumpulan data dalam periode tertentu. Pada saat wawancara, peneliti sudah melakukan analisis terhadap jawaban yang diwawancarai. Bila jawaban yang diwawancarai setelah dianalisis belum memuaskan, maka peneliti akan melanjutkan pertanyaan lagi, sampai tahap tertentu data dianggap kredibel.

Miles dan Huberman (1984) dalam Sugiyono (2013) mengemukakan bahwa aktivitas dalam analisis data kualitatif dilakukan secara interaktif dan berlangsung secara terus-menerus sampai tuntas, sehingga datanya sudah jenuh. Aktivitas dalam analisis data adalah reduksi data, penyajian data, dan conclusion drawing/verification.

\section{Keabsahan Data}

Dalam penelitian ini menggunakan uji keabsahan data melalui uji kredibilitas menggunakan triangulasi dan uji transferability merupakan validitas eksternal dalam penelitian kualitatif. Vadilitas eksternal menunjukkan derajat ketepatan. Agar orang lain dapat memahami hasil penelitian kualitatif maka peneliti dalam membuat laporannya harus memberikan uraian yang rinci, jelas, sistematis dan dapat dipercaya. Dengan demikian, pembaca menjadi jelas atas hasil penelitian tersebut sehingga dapat memutuskan dapat atau tidaknya diaplikasikan di tempat lain. Setelah data direduksi maka data akan ditampilkan. Data tersebut dapat dimasukkan ke dalam hasil penelitian untuk memperkuat data sehingga data menjadi rinci, jelas, sistematis, dan dapat dipercaya sehingga pembaca menjadi jelas. (Sugiyono, 2013)

\section{HASIL DAN PEMBAHASAN}

Makna kerja merupakan orientasi yang ditetapkan seseorang terhadap pekerjaannya. Bekerja sebagai abdi dalem dimaknai bahwa pekerjaan yang mereka jalani dipercaya bahwa apa yang dilakukannya akan mampu memberikan kontribusi kepada lingkungan sosial atau untuk melayani diri sendiri dan orang lain. Kecintaannya pada kesenian keraton membuat mereka merasa terpanggil untuk ikut berkontribusi dalam melestarikan budaya Jawa khususnya budaya Keraton Ngayogyakarta Hadiningrat. Seteleh menerima Danais pun tak mengubah makna kerjanya.

“Iya. Dari Senin sampai Minggu. Dari jam sembilan sampai jam dua (siang). Sekarang saja sudah menggunakan fingerprint. Yang belum menggunakan kan hanya Kredamardawa. Di sana masih menggunakan tanda tangan. Ketika datang tanda tangan karena itu dinilai. Saya dulu menjadi abdi dalem hanya memperoleh kekucah Rp 2.500,-. Tapi sekarang berbeda. Untuk masalah 
kekucah itu hak kanjeng pangeran. Kita hanya menerima saja. Sendiko saja. Dulu untuk menunjang kesejahteraan mendapatkan seratus per bulan. Jadi empat ratus per empat bulan sebagai uang kesejahteraan abdi dalem. Sekarang berbeda karena ada Danais. Caos itu berasal dari caosan. Caos itu artinya memberi. Memberi itu tidak butuh pengembalian. Jadi kalau datang baru dicaosi. Saya dulu juga dari caos. Diberi ya sembah nuwun, tidak diberi nggih sembah nuwun. Itu abdi dalem. Lebih baik lagi ngarso dalem. Lebih baik banyak memberi daripada menerima. Memberi itu tidak butuh pengembalian. Kamu akan merasakan tidak enak apabila kamu memberikan tapi saya harus mengembalikan. Itu untuk yang muda-muda. Makanya di keraton itu diajarkan credo watak satriya. Isinya nyawiji, artinya berserah diri kepada Tuhan; greret itu dihayati, sengguh itu percaya diri, dan ora mingkuh, itu tidak gentar dalam menghadapi ujian dan hambatan. Selain itu golong giling, srawung lan ngeluru papat, hamemayu hayuning bawana. Lain kalau yang seperti saya, $\mathrm{Bu}$ Harti, yang sepuh-sepuh itu hampir sama. Karena saya menganggap menjadi abdi dalem merupakan sebuah talenta dan garis, abdi dalem itu terpanggil dan memang dibutuhkan.” (Tarno, 18/02/2020, 17.00)

Makna kerja merupakan sekumpulan nilai-nilai, keyakinan-keyakinan, sikap, dan harapan yang orang-orang miliki dalam kaitannya dengan kerja (Gaggioti dalam Siti, 2013). Menurut Wrzesniewski et al., (2003) terdapat tiga aspek penting para pegawai dalam melakukakan pekerjaannya, yakni bekerja sebagai sebuah pekerjaan, pekerjaan sebagai sebuah karir, dan pekerjaan sebagai sebuah panggilan. Hasil penelitian ini menyatakan bahwa aspek terpenting yang dimaknai dalam bekerja adalah pekerjaan sebagai sebuah panggilan. Abdi dalem merupakan sumber kebermaknaan diri. Mereka memandang pekerjaan sebagai sebuah panggilan dan percaya bahwa pekerjaan yang dilakukannya mampu memberikan kontribusi kepada lingkungan sosial atau sebagai sarana untuk melayani diri sendiri maupun orang lain.

Para abdi dalem tidak memaknainya sebagai pekerjaan karena bekerja sebagai abdi dalem tidak dijadikan sebagai pendapatan pokok. Mereka juga tidak berpikir untuk berhenti menjadi abdi dalem karena tidak memperoleh pendapatan. Abdi dalem juga tidak memaknainya sebagai sebuah karir. Hal ini dikarenakan dalam bekerja, tidak terdapat kebutuhan untuk bersaing. Meskipun abdi dalem tetap memiliki motivasi untuk berprestasi dan meningkatkan kepuasan. Alasannya karena mereka tunduk dan patuh terhadap segala aturan dan keputusan yang dibuat oleh ngarso dalem (raja). Jadi mereka menerima apapun yang diputuskan oleh rajanya.

Hasil penelitian yang disampaikan oleh Witshire (2015) tentang makna kerja dalam skema pekerjaan publik di Afrika Selatan menunjukkan bahwa bekerja dalam skema pekerjaan publik tidak hanya memiliki makna kerja kegiatan ekonomi, rutinitas terstruktur, kepuasan intrinsik, pengalaman interpersonal, status sosial, dan aktivitas yang benar secara moral tetapi juga gender dan kesempatan untuk pelatihan. Selain itu terdapat hasil penelitian dari Spinelli-DeSa et al., (2017) yang menyakan bahwa makna kerja merupakan mekanisme harga diri, self efficacy, tujuan dan rasa memiliki yang layak dilakukan karena 
keberhasilan yang karyawan wanita taklukkan dalam lingkungan kerja yang sangat kompetitif. Faktor lainnya adalah pendapatan yang diperoleh. Ini berbeda dengan abdi dalem dalam memaknai kerjanya. Mereka tidak berpikir tentang kegiatan ekonomi, pendapatan, dan kepentingan pribadi.

\section{KESIMPULAN}

Berdasarkan penelitian yang telah dilakukan, maka kesimpulannya dari penelitian ini, yakni pekerjaan bagi para abdi dalem dimaknai sebagai sebuah panggilan. Abdi dalem memandang pekerjaan sebagai sebuah panggilan dan percaya bahwa pekerjaan yang dilakukannya mampu memberikan kontribusi kepada lingkungan sosial atau sebagai sarana untuk melayani diri sendiri maupun orang lain. Ada atau tidaknya gaji bagi abdi dalem baik dari kekucah maupun Dana Keistimewan, tak mengubah makna kerjanya. 


\section{DAFTAR PUSTAKA}

Anugraheni, E. 2013. Abdi Dalem Keraton Dapet Gaji Minimal Rp 600 Ribu dari Dana Keistimewaan. Diakses pada tanggal 1 Februari 2018 jam 03.20 WIB dari jogja.tribunnews.com.

Awo, M. 2018. Abdi Dalem Jogja Digaji Dengan Dana Istimewa. Diakses pada tanggal 7 Maret 2020 jam 19.39 WIB dari joss.co.id.

BPKP. 2015. Keistimewaan Yogyakarta. Diakses pada tanggal 1 Februari 2018 jam 03.20 WIB dari www.bpkp.go.id.

Esterberg, K. G. 2002. Qualitative Methods In Social Research. Mc Graw Hill: New York.

Herudiarti, S. E. 2013. Makna Kerja Bagi Satuan Pengaman (Security) Perempuan (Studi Fenomenologi Satpam Perempuan Jawa). Tesis. Program Magister Sains Psikologi Fakultas Psikologi: Universitas Gadjah Mada Yogyakarta.

Koeswara, E. 1992. Logoterapi: Psikologi Viktor Frankl. Yogyakarta: Kanisius.

Kratonjogja.id. 2016. Tugas dan Fungsi Abdi Dalem. Diakses pada tanggal 20 Januari 2019 jam 11.59 WIB dari kratonjogja.id.

Kurniawan, H. 2012. 186 Kerajaan Masih Eksis di Indonesia. Diakses pada tanggal 1 Januari 2019 jam 03.33 WIB dari sindonews.com.

Moleong, L. J. 2008. Metodologi Pemelitian Kulaitatif Edisi Revisi. Bandung: PT Remaja Rosdakarya.

Prabowo. 2011. Menelisik Abdi Dalem Keraton Ngayogyogyakarta. Diakses pada tanggal 1 Februari 2018 jam 02.03 WIB dari okezone.com.

Siti, N. A. 2013. Makna Kerja (Meaning of Work) Suatu Studi Etnografi Abdi Dalem Keraton Ngayogyakarta Hadiningrat Daerah Istimewa Yogyakarta. Jurnal Psikologi Industri dan Organisasi, vol 02(1).

Soenarto, D. 2012. Kesetiaan Pengabdian Abdi Dalem. Yogyakarta: Kepel Press. Spinelli-de-Sá, J. G., Lemos, A. H. C., \& Cavazotte, F. 2017. Making A Career In A Male-Dominated Field: The Meaning Of Work For Women Employed In The Financial Markets. Revista de Administração Mackenzie, vol 18(4), p:109-136. https://doi10.1590/1678-69712017/administracao.v1 8n4p109136.

Sugiyono. 2013. Metode Penelitian Kuantitatif, Kualitatif, dan R\&D. Bandung: Alfabeta.

Yin, R. K. 2014. Case Study Research Design dan Methods ( $5^{\text {th }}$ ed.). Thousand Oaks, CA: Sage.

Wiltshire, A. H. 2016. The Meanings Of Work In A Public Work Scheme In South Africa. International Journal of Sociology and Social Policy, Vol. 36 Issue: 1/2, pp.2-17, https://doi.org/10.1108/IJSSP-02-2015-0014.

Wrzesniewski, A., Dutton, J.E., \& Debebe, G. 2003. Interpersonal Sensemaking and The Meaning of Work. Research in Organizational Behavior, vol 25, p: 93-135.

Bisman (Bisnis dan Manajemen): The Journal Of Business and Management 